\title{
Correction to: Promises and Pitfalls of Latent Variable Approaches to Understanding Psychopathology: Reply to Burke and Johnston, Eid, Junghänel and Colleagues, and Willoughby
}

\author{
G. Leonard Burns ${ }^{1} \cdot$ Christian Geiser $^{2} \cdot$ Mateu Servera $^{3} \cdot$ Stephen P. Becker ${ }^{4} \cdot$ Theodore P. Beauchaine $^{5}$ \\ Published online: 7 September 2020 \\ (C) Springer Science+Business Media, LLC, part of Springer Nature 2020
}

Correction to: Journal of Abnormal Child Psychology (2020) 48:917-922

https://doi.org/10.1007/s10802-020-00656-1

The original version of this article unfortunately contained a mistake. The supplementary material was not captured to our commentary article.

Publisher's Note Springer Nature remains neutral with regard to jurisdictional claims in published maps and institutional affiliations.

The online version of the original article can be found at https://doi.org/ 10.1007/s10802-020-00656-1

Electronic supplementary material The online version of this article (https://doi.org/10.1007/s10802-020-00690-z) contains supplementary material, which is available to authorized users.

\footnotetext{
G. Leonard Burns glburns@wsu.edu

1 Department of Psychology, Washington State University, Pullman, WA, USA

2 Utah State University, Logan, UT 84322, USA
}

3 University of the Balearic Islands, Carretera de Valldemossa, km 7.5, 07122 Palma, Illes Balears, Spain

4 Cincinnati Children's Hospital Medical Center and University of Cincinnati College of Medicine, 2600 Clifton Ave, Cincinnati, OH 45221, USA

5 The Ohio State University, Columbus, OH, USA 